\title{
Appendicitis scores may be useful in reducing the costs of treatment for right lower quadrant pain
}

\author{
Apandisit skorları, sağ alt kadran ağrısı için \\ tedavi maliyetlerini düşürmede faydalı olabilir
}

\author{
Cüneyt KIRKIL, ${ }^{1}$ Koray KARABULUT, ${ }^{1}$ Erhan AYGEN, ${ }^{1}$ Yavuz Selim ILHAN, ${ }^{1}$ \\ Mesut YUR, ${ }^{1}$ Kenan BİNNTOĞLU, ${ }^{1}$ Nurullah BÜLBÜLLER ${ }^{2}$
}

\section{BACKGROUND}

Unnecessary hospital admissions and negative appendectomies increase healthcare costs of patients with right lower quadrant (RLQ) pain. This study aimed to evaluate the impact on the cost of treatment of appendicitis scoring systems.

\section{METHODS}

Charts were reviewed of patients admitted to the general surgery ward of our hospital with RLQ pain within a year. Alvarado and Lintula scores were calculated, and a simulation was performed to determine the treatment charges that would have been generated had the scoring recommendations been used for admission and surgical decision-making.

\section{RESULTS}

Of the 114 admitted patients, 64 (56\%) underwent appendectomy. The rate of negative appendectomy was $17.2 \%$. The overall accuracy rates of the Alvarado and Lintula scores for both 'admit' and 'operate' decision-making were $82.7 \%$ and $91.9 \%$, respectively $(\mathrm{p}=0.102)$. Total charges for the 114 patients were $\$ 39,655$. If the Alvarado or Lintula score had been used, the total treatment charges would have been $\$ 34,087$ and $\$ 25,772$ ( $\mathrm{p}=0.015$ and $\mathrm{p}=0.000$ ), with negative appendectomy rates of $18.5 \%$ and $3.6 \%$, respectively.

\section{CONCLUSION}

The implementation of Alvarado and Lintula scores for the decision of hospital admission and appendectomy would have reduced overall treatment charges for acute RLQ pain.

Key Words: Acute appendicitis; Alvarado scores; cost; Lintula scores; score.

\section{AMAÇ}

Sağ alt kadran (SAK) ağrısı olan hastaların gereksiz hastane yatışları ve negatif apendektomiler tedavi giderlerini artırır. Bu çalışmada, apandisit skorlama sistemlerinin tedavi maliyetine etkisi değerlendirildi.

\section{GEREÇ VE YÖNTEM}

Bir yıl içinde SAK ile hastanemiz genel cerrahi kliniğine kabul edilen hastaların kayitları incelendi. Alvarado ve Lintula skorları hesaplandı. Hastaneye yatış ve cerrahi tedavi kararında skorlama önerileri kullanılmış olsaydı, tedavi giderlerinin ne olacağını saptamak için bir benzetim çalışması düzenlendi.

\section{BULGULAR}

Yüz on dört hastanın 64'üne (\%56) apendektomi yapıldı. Negatif apendektomi oranı \%17,2 idi. Alvarado ve Lintula skorlarının yatış ve tedavi kararı vermedeki genel doğruluk oranları sırasıyla $\% 82,7$ ve $\% 91,9$ idi $(p=0,102)$. Hastaların tümü için toplam tedavi maliyeti 39,655 \$ idi. Alvarado ve Lintula skorları kullanılmış olsaydı toplam tedavi giderleri sirasiyla $34,087 \$$ ve $25,772 \$(\mathrm{p}=0,015$ ve $\mathrm{p}=0,000)$; negatif apendektomi oranları $\% 18,5$ ve $\% 3,6$ olacaktı.

\section{SONUÇ}

Alvarado ve Lintula skorlarının hastaneye kabul ve apendektomi kararı için kullanılması akut SAK ağrısı için tedavi giderlerini düşürecektir.

Anahtar Sözcükler: Akut apandisit; Alvarado skoru; maliyet; Lintula skoru; skor.
${ }^{1}$ Department of General Surgery, Firat University, Faculty of Medicine, Elazığ; ${ }^{2}$ Department of General Surgery, Antalya Training and Research Hospital, Antalya, Turkey.
${ }^{1}$ Frrat Üniversitesi Tıp Fakültesi, Genel Cerrahi Anabilim Dalı, Elazığ; ${ }^{2}$ Antalya Eğitim ve Araştırma Hastanesi, Genel Cerrahi Kliniği, Antalya. 
Abdominal pain is a common presenting complaint of emergency department (ED) patients who are admitted to general surgery wards. Making an early diagnosis of appendicitis, one of the causes of an acute abdomen, can be difficult. Typical symptoms, signs, and supportive laboratory data are not present in 20 $33 \%$ of acute abdominal pain patients in whom acute appendicitis is the primary working diagnosis..$^{[1,2]} \mathrm{De}$ lay in diagnosis may lead to perforation, periappendicular abscess, wound infection, and intraabdominal adhesions. In the past, it was believed that the most effective way to avoid these complications was to broaden surgical indications at the expense of an increased rate (up to $40 \%$ ) of negative appendectomy. ${ }^{[3-5]}$ The downsides of this approach are increased hospital bed utilization, higher treatment costs, and loss of productivity.

The Alvarado (Table 1) and Lintula (Table 2) scoring tools were developed in an attempt to assist clinicians in distinguishing acute appendicitis from other causes of abdominal pain, with the aim of reducing the negative appendectomy rate. ${ }^{[6-12]}$ Acute abdominal pain patients with a total score of $\leq 3$ on the Alvarado and $\leq 15$ on the Lintula scales have a lower probability of acute appendicitis and thus do not require hospitalization. Patients with scores of $\geq 7$ and $\geq 21$, respectively, have a higher probability of acute appendicitis requiring emergency appendectomy. Patients with Alvarado scores between 4 and 6 and Lintula scores between 16 and 20 are suspected cases for acute appendicitis; close inpatient follow-up is recommended for this group. ${ }^{[13,14]}$

We performed a retrospective simulation to determine how charges would have changed if the Alvarado and Lintula appendicitis scoring systems had been used in patients admitted to our department due to right lower quadrant (RLQ) pain. A secondary objective of the study was to determine the diagnostic accuracy of the Alvarado and Lintula scoring systems.

\section{MATERIALS AND METHODS}

Charts of patients presenting with RLQ pain to the ED of our hospital between November 2009 and November 2010 and admitted to the general surgery inpatient ward were analyzed. Exclusion criteria included prior appendectomy, concurrent antibiotic therapy, chronic RLQ pain, abdominal trauma, and inguinal hernia. All patients underwent ultrasound (US) examination by a radiology resident in the ED. If the US findings were not consistent with clinical findings, an oral and intravenous (IV) contrast-enhanced multislice computed tomography (CT) was performed. "Clinical decision" was defined as the treatment decision that was reached after the evaluation of medical history, physical examination, laboratory tests, and
Table 1. Alvarado score

\begin{tabular}{lc}
\hline & Score \\
\hline Symptoms & \\
$\quad$ Migratory right iliac fossa pain & 1 \\
$\quad$ Anorexia & 1 \\
$\quad$ Nausea/vomiting & 1 \\
Signs & \\
$\quad$ Right lower quadrant tenderness & 2 \\
$\quad$ Right iliac fossa rebound & 1 \\
$\quad$ Elevation of temperature & 1 \\
Laboratory findings & \\
$\quad$ Leukocytosis & 2 \\
$\quad$ Left shift (neutrophils) & 1 \\
Total score & 10 \\
\hline
\end{tabular}

imaging studies. Patients without a diagnosis of acute appendicitis were admitted for close clinical followup; they were kept nil per os (NPO), received maintenance IV fluids, and IV H2-receptor blockers as stress ulcer prophylaxis.

The Alvarado and Lintula scores of the patients were calculated by a staff surgeon, and in case appen-

Table 2. Lintula score

\begin{tabular}{|c|c|}
\hline & Score \\
\hline \multicolumn{2}{|l|}{ Gender } \\
\hline Male & 2 \\
\hline Female & 0 \\
\hline \multicolumn{2}{|l|}{ Intensity of pain } \\
\hline Severe & 2 \\
\hline Mild or moderate & 0 \\
\hline \multicolumn{2}{|l|}{ Migration of pain } \\
\hline Present & 4 \\
\hline Absent & 0 \\
\hline \multicolumn{2}{|l|}{ Right lower quadrant pain } \\
\hline Present & 4 \\
\hline Absent & 0 \\
\hline \multicolumn{2}{|l|}{ Vomiting } \\
\hline Present & 2 \\
\hline Absent & 0 \\
\hline \multicolumn{2}{|l|}{ Body temperature } \\
\hline$\geq 37.5^{\circ} \mathrm{C}$ & 3 \\
\hline$<37.5^{\circ} \mathrm{C}$ & 0 \\
\hline \multicolumn{2}{|l|}{ Guarding } \\
\hline Present & 4 \\
\hline Absent & 0 \\
\hline \multicolumn{2}{|l|}{ Bowel sounds } \\
\hline Absent, tinkling or high-pitched & 4 \\
\hline Normal & 0 \\
\hline \multicolumn{2}{|l|}{ Rebound tenderness } \\
\hline Present & 7 \\
\hline Absent & 0 \\
\hline Total score & 32 \\
\hline
\end{tabular}


dectomy had been performed, the pathology report was used as the final diagnosis. Patients whose abdominal pain resolved spontaneously within the first 24 hours of observation, without undergoing appendectomy, were considered not to have acute appendicitis. The hospital charges incurred after evaluation in the ED were calculated from the sum of invoices issued by the government insurance agency to the patient.

\section{Simulation study design}

Low-score group ( $\leq 3$ for Alvarado, $\leq 15$ for Lintula): These patients were considered to probably not have acute appendicitis, and thus discharge home from the ED would be appropriate. As this group would not have been hospitalized, their post-ED charges were taken to be $\$ 0$. The charges for patients who had low scores but who underwent appendectomy, and in whom the pathology was positive for appendicitis, were used as they were, without adjustment.

Mid-score group (4-6 for Alvarado, 16-20 for Lintula): The treatment costs of those who underwent appendectomy, and in whom the pathology was positive for appendicitis, and of those who were followed closely on the ward without surgery and who had no progression to appendicitis were used as they were, without adjustment. In cases of negative appendectomy, surgery and anesthesia-related charges were subtracted from the patient's total treatment-related bill.

High-score group ( $\geq 7$ for Alvarado, $\geq 21$ for Lintula): The treatment costs of those who underwent positive or negative appendectomy were used as they were. If the scoring systems had been used for decision-making, the patients whose symptoms spontaneously resolved in this group would have undergone a negative appendectomy. Their treatment costs were assumed to be $\$ 454$, the average invoice amount of appendectomized patients in this study.

\section{Outcome measures}

The sensitivity, specificity, positive predictive value (PPV), negative predictive value (NPV), and diagnostic accuracy rates of the scoring systems and charges for treatment were calculated.

\section{Statistics}

Differences between the actual and calculated treatment charges had the Alvarado and Lintula scores been used were analyzed with paired t-testing and 95\% confidence intervals. The differences between the sensitivity, specificity, PPV, NPV, and diagnostic accuracy rates of the scoring systems and the actual clinical decision were tested using chi-square testing and $95 \%$ confidence intervals. Pearson correlation coefficients were calculated in order to determine the relationship between the Alvarado score, Lintula score, and pathology result.

\section{RESULTS}

During the study period, 127 patients with a primary complaint of RLQ pain were evaluated in the ED and referred to the general surgery clinic. Of these, data from the charts of 13 patients were excluded for the following reasons: 1 for having had a prior appendectomy, 6 for concurrent use of antibiotics, 4 for a history of chronic abdominal pain, 1 for a history of abdominal trauma, and 1 for presence of a right inguinal hernia.

In the remaining 114 patients, Alvarado and Lintula scores were calculated. In these patients, US was consistent with acute appendicitis in 56 (49.1\%). Only 4 of 22 patients who underwent oral and IV contrastenhanced CT had a radiologic diagnosis of probable acute appendicitis. Appendectomy was performed in 64 of the 114 patients $(56.1 \%$; 33 laparoscopic appendectomies, 31 open appendectomies). Histopathological examination was negative for acute appendicitis in 11 of these 64 patients $(17 \%$; 1 of 33 laparoscopic appendectomies, 10 of 31 open appendectomies).

The total bill for the services provided in the general surgery department was $\$ 39,655$ : mean of $\$ 454$ per patient who underwent appendectomy (\$345 in the open appendectomy group and $\$ 563$ in the laparoscopic appendectomy group) and $\$ 208$ per patient

Table 3. Sonographic and histopathologic results in 22 patients with right lower quadrant pain who underwent CT in addition to ultrasound scanning

\begin{tabular}{|c|c|c|c|c|}
\hline Computed tomography & Ultrasound & Management & No. of patients & Histopathology \\
\hline \multirow{4}{*}{ Normal } & \multirow{2}{*}{ Normal } & Observation & 14 & \multirow{3}{*}{ Appendicitis in all 3} \\
\hline & & Appendectomy & 3 & \\
\hline & \multirow[t]{2}{*}{ Appendicitis } & Observation & 0 & \\
\hline & & Appendectomy & 1 & \multirow[t]{2}{*}{ Normal appendix } \\
\hline \multirow[t]{4}{*}{ Appendicitis } & \multirow[t]{2}{*}{ Normal } & Observation & 1 & \\
\hline & & Appendectomy & 2 & \multirow[t]{2}{*}{ Appendicitis in both } \\
\hline & \multirow[t]{2}{*}{ Appendicitis } & Observation & 0 & \\
\hline & & Appendectomy & 1 & Appendicitis \\
\hline
\end{tabular}


Table 4. Patient management and histopathological results according to the Alvarado and Lintula scores in 114 patients admitted with right lower quadrant pain

\begin{tabular}{lccc}
\hline & & \multicolumn{2}{c}{ Appendectomy } \\
\cline { 3 - 4 } & Observation & Normal appendix & Appendicitis \\
\hline Alvarado score & & 3 & 2 \\
$\quad \leq 3$ & 22 & 5 & 9 \\
$4-6$ & 19 & 3 & 42 \\
$\geq 7$ & 9 & & \\
Lintula score & & 7 & 5 \\
$\leq 15$ & 46 & 2 & 22 \\
$16-20$ & 4 & 2 & 26 \\
$\geq 21$ & 0 & & \\
\hline
\end{tabular}

who was observed on the ward without appendectomy.

Of the 56 patients who had US findings compatible with acute appendicitis, 10 recovered spontaneously during inpatient observation, and 46 underwent appendectomy (6 negative, 40 positive). Of the 58 patients who did not have US findings compatible with acute appendicitis, 40 recovered spontaneously during inpatient observation, and 18 underwent appendectomy (5 negative, 13 positive). The US and histopathology results of 22 patients who were also investigated by $\mathrm{CT}$ are summarized in Table 3.

Table 4 lists the distribution of Alvarado and Lintula scores of the patients. Had the Alvarado score been implemented for decision-making, 22 patients with a score of $\leq 3$ would not have been hospitalized, and $\$ 7,319$ would not have been charged. Eight patients with a score of $<7$ would not have undergone a negative appendectomy, and $\$ 4,017$ would not have been charged. Had an Alvarado score of $\geq 7$ been used to operate and perform an appendectomy, nine additional patients would have undergone a negative appendectomy (a negative appendectomy rate of $18.5 \%$ ), resulting in $\$ 4,085$ in charges. The actual total charges for these patients, who were in fact observed, was $\$ 1,649$. Two patients with initial Alvarado scores of $\leq 3$ turned out to have acute appendicitis on their pathology reports, a false-negative rate of $4.5 \%$ if the Alvarado score had been used for decision-making. We assumed that the charges of these two patients, who would have presented eventually and undergone emergent appendectomy, would not have changed from their actual charges. Thus, total charges would have been $\$ 34,087$ instead of 39,655 , a $14 \%$ difference $(\mathrm{p}=0.015)$.

Had the Lintula score been used for decision-making, 58 patients with a score of $\leq 15$ would not have been unnecessarily hospitalized. The treatment cost of these patients was $\$ 15,519$. Nine patients with scores $<21$ would not have undergone a negative appendec- tomy, and $\$ 4,516$ in charges would have been avoided. All 28 patients with a score of $\geq 21$ were operated, and all but two had a pathology diagnosis of appendicitis. Had the Lintula score been implemented, the negative appendectomy rate would have been $3.6 \%$. Five of 58 patients with a Lintula score $<15$ turned out to have acute appendicitis, a false-negative rate of $16.1 \%$. We assumed that the charges of these five patients, who would have presented eventually and undergone emergent appendectomy, would not have changed from their actual charges. Charges of patients whose treatment decisions would not have been different if the Lintula score had been used were used as is. Thus, if the Lintula score has been used, total charges would have been $\$ 25,772$. This figure is significantly lower than actual charges incurred in our patient group $(\mathrm{p}=0.000)$.

The sensitivity, specificity, PPV, NPV, and diagnostic accuracy rates of the Alvarado score, Lintula score, and clinical decisions are depicted in Table 5. Sensitivity of the Lintula score was significantly lower than of clinical decision-making $(p=0.006)$, but the difference between the sensitivity of the Alvarado and Lintula scores was not statistically significant $(\mathrm{p}=0.118)$. On the other hand, the specificity of the Lintula score was significantly greater than both the Alvarado score and clinical decision-making ( $p=0.000$ and $p=0.018$, respectively). The difference in specificity between the Alvarado score and clinical decision-making was insignificant $(\mathrm{p}=0.140)$. The Alvarado and Lintula scores correlated highly with the histopathological results (Pearson correlation testing, $\mathrm{p}=0.001$ and $\mathrm{p}=0.000$, respectively).

\section{DISCUSSION}

The lifelong incidence of acute appendicitis ranges between $5-25 \%$, and appendectomy is the most frequently performed emergency abdominal surgery in the world; in the United States alone, 250,000 appen- 
dectomies are performed annually, using one million hospital days and costing 3 billion dollars per year. [15-20] To minimize expenditures while providing the highest quality of service, unnecessary appendectomies should be avoided. Our study demonstrated that common scoring systems used to reduce negative appendectomy rates also significantly reduced treatment charges.

The preoperative diagnosis of acute appendicitis is usually based on clinical findings, but these are only $60-80 \%$ accurate due to atypical presentations and the presence of other diseases that cause RLQ pain. ${ }^{[21,22]}$ While US is the most frequently used imaging method to confirm the diagnosis, diagnostic accuracy rates (71\% and $97 \%$ ) are limited by practitioner experience, localization of the appendix, the patient's body mass index, and density of bowel gases. ${ }^{[23-25]} \mathrm{CT}$ is a more reliable imaging method for diagnosing acute appendicitis, having a diagnostic accuracy rate of $93-98 \%$. ${ }^{[26]}$ The training and experience of the radiologist significantly affects the accuracy of CT imaging. ${ }^{[27]}$ On the other hand, CT has disadvantages such as contrastrelated complications, exposure to ionizing radiation, and high costs. Therefore, US is the preferred imaging modality in pregnant and breastfeeding women, as well as in children. ${ }^{[28]}$ For these reasons, US and $\mathrm{CT}$ should be considered complementary techniques, rather than rivals. In SCOAP (Surgical Care and Outcomes Assessment Program), the prevalence of negative appendectomy was found to be higher in patients with conflicting US/CT findings. ${ }^{[29]}$ In our series, the diagnostic accuracy of CT (74.6\%) was lower than is commonly reported in the literature, probably due to the fact that radiology residents were reading the emergency CT scans. In addition, CT scanning was performed in only a small proportion of our patients, making meaningful statistical comparisons of the CT results with other parameters impossible.

In our patients, a diagnostic accuracy rate of $90.4 \%$ was achieved by clinical examination aided by laboratory and imaging findings. In 1986, when Alvarado proposed a scoring system for the early diagnosis of acute appendicitis, CT and US imaging were not com- monly used. ${ }^{[6]}$ In subsequent years, others developed scoring systems based on symptoms as well as associated clinical and laboratory findings ${ }^{[7-12]}$ The sensitivity, specificity, and diagnostic accuracy of the Alvarado score were reported to be between 84.2-92\%, 66.7$91.2 \%$, and $87-92 \%$, respectively. ${ }^{[30-33]}$ The sensitivity, specificity, and diagnostic accuracy of the Lintula score in adults are reported to be $87 \%, 98 \%$, and $91 \%$, respectively. ${ }^{[14]}$ All three articles found through a PubMed-based literature research on the Lintula scoring system are written by Lintula et al..$^{7,14,34]}$ According to the results of the present study, the diagnostic accuracy of the Alvarado and Lintula scoring systems in our patients was consistent with the existing literature. We found the specificity of the Lintula score to be very high; thus, had the Lintula score been used for decision-making, our negative appendectomy rates would have been significantly lower.

The Alvarado score has been found to be most accurate in men and children. ${ }^{[35]}$ Having used a modified Alvarado score, Kanumba et al. ${ }^{[36]}$ found sensitivity, specificity, and diagnostic accuracy rates to be different for men and women $(95.8 \%, 92.9 \%$, and $91.5 \%$ versus $88.3 \%, 89.7 \%$ and $87.6 \%$, respectively). In the Lintula scoring system, however, the sex of the patient is considered a separate parameter. In our patients, only two women had a Lintula score of $\geq 21$; thus, subgroup analyses by sexes were not performed.

We found high NPVs for the Alvarado and Lintula scoring systems (91.4\% and $92.6 \%$, respectively), which means a low false-negativity rate in patients with a low score. Therefore, imaging of patients with a low appendicitis score is not recommended. Supporting this, McKay and Shepherd ${ }^{[13]}$ reported that CT imaging in 52 out of the 55 patients with an Alvarado score of $\leq 3$ was negative $(94.5 \%)$, and the incidence of delayed presentation of acute appendicitis was only $3.6 \%$. They even argued that because the incidence of acute appendicitis in patients with an Alvarado score of $\geq 7$ was $77.7 \%$, these patients should be referred directly to surgery without $\mathrm{CT}$ imaging in the ED.

Although acute appendicitis is considered to result from progressive inflammation, spontaneous resolu-

Table 5. The sensitivity, specificity, positive predictive value, negative predictive value and diagnostic accuracy rates of the Alvarado and Lintula scores and clinical decision in patients with right lower quadrant pain

\begin{tabular}{lcccc}
\hline & Alvarado & Lintula & Clinical decision & $p$ \\
\hline Sensitivity (\%) & 95.5 & 83.9 & 100 & 0.007 \\
Specificity (\%) & 67.6 & 96.4 & 82.0 & 0.001 \\
Positive predictive value (\%) & 77.8 & 92.9 & 82.8 & 0.228 \\
Negative predictive value (\%) & 92.6 & 91.4 & 100 & 0.111 \\
Diagnostic accuracy (\%) & 82.7 & 91.9 & 90.4 & 0.133 \\
\hline
\end{tabular}


tion has also been reported. ${ }^{[37-40]}$ Our assumption that spontaneously resolving cases were not true acute appendicitis may be criticized. However, the incidence of spontaneously healing acute appendicitis is not known. Scoring of patients with RLQ pain can be repeated during active observation while patients are worsening or improving clinically; symptoms and signs resolve completely in some patients. ${ }^{[1]}$

In this retrospective study, both the Alvarado and Lintula scoring systems had high diagnostic accuracy rates for acute appendicitis. Treatment charges would have been significantly lower had these scores been utilized for decision-making in patients with acute RLQ pain.

\section{Conflict-of-interest issues regarding the authorship} or article: None declared.

\section{REFERENCES}

1. Lewis FR, Holcroft JW, Boey J, Dunphy E. Appendicitis. A critical review of diagnosis and treatment in 1,000 cases. Arch Surg 1975;110:677-84.

2. Berry J Jr, Malt RA. Appendicitis near its centenary. Ann Surg 1984;200:567-75.

3. Velanovich V, Satava R. Balancing the normal appendectomy rate with the perforated appendicitis rate: implications for quality assurance. Am Surg 1992;58:264-9.

4. Simpson J, Speake W. Appendicitis. Clin Evid 2005;14:52935 .

5. Andersson RE. Meta-analysis of the clinical and laboratory diagnosis of appendicitis. Br J Surg 2004;91:28-37.

6. Alvarado A. A practical score for the early diagnosis of acute appendicitis. Ann Emerg Med 1986;15:557-64.

7. Lintula H, Kokki H, Kettunen R, Eskelinen M. Appendicitis score for children with suspected appendicitis. A randomized clinical trial. Langenbecks Arch Surg 2009;394:999-1004.

8. Christian F, Christian GP. A simple scoring system to reduce the negative appendicectomy rate. Ann R Coll Surg Engl 1992;74:281-5.

9. Dado G, Anania G, Baccarani U, Marcotti E, Donini A, Risaliti A, et al. Application of a clinical score for the diagnosis of acute appendicitis in childhood: a retrospective analysis of 197 patients. J Pediatr Surg 2000;35:1320-2.

10. Samuel M. Pediatric appendicitis score. J Pediatr Surg 2002;37:877-81.

11. Eskelinen M, Ikonen J, Lipponen P. A computer-based diagnostic score to aid in diagnosis of acute appendicitis. Theor Surg 1992; 7:86-90.

12. Fenyö G, Lindberg G, Blind P, Enochsson L, Oberg A. Diagnostic decision support in suspected acute appendicitis: validation of a simplified scoring system. Eur J Surg 1997;163:831-8.

13. McKay R, Shepherd J. The use of the clinical scoring system by Alvarado in the decision to perform computed tomography for acute appendicitis in the ED. Am J Emerg Med 2007;25:489-93.

14. Lintula H, Kokki H, Pulkkinen J, Kettunen R, Gröhn O, Eskelinen M. Diagnostic score in acute appendicitis. Validation of a diagnostic score (Lintula score) for adults with suspected appendicitis. Langenbecks Arch Surg 2010;395:495-500.

15. Flum DR, Koepsell T. The clinical and economic correlates of misdiagnosed appendicitis: nationwide analysis. Arch Surg 2002;137:799-804.

16. Flum DR, Morris A, Koepsell T, Dellinger EP. Has misdiagnosis of appendicitis decreased over time? A populationbased analysis. JAMA 2001;286:1748-53.

17. Guller U, Jain N, Curtis LH, Oertli D, Heberer M, Pietrobon $\mathrm{R}$. Insurance status and race represent independent predictors of undergoing laparoscopic surgery for appendicitis: secondary data analysis of 145,546 patients. J Am Coll Surg 2004;199:567-77.

18. Margenthaler JA, Longo WE, Virgo KS, Johnson FE, Oprian CA, Henderson WG, et al. Risk factors for adverse outcomes after the surgical treatment of appendicitis in adults. Ann Surg 2003;238:59-66.

19. Sugimoto T, Edwards D. Incidence and costs of incidental appendectomy as a preventive measure. Am J Public Health 1987;77:471-5.

20. Davies GM, Dasbach EJ, Teutsch S. The burden of appendicitis-related hospitalizations in the United States in 1997. Surg Infect (Larchmt) 2004;5:160-5.

21. Bendeck SE, Nino-Murcia M, Berry GJ, Jeffrey RB Jr. Imaging for suspected appendicitis: negative appendectomy and perforation rates. Radiology 2002;225:131-6.

22. Ashraf K, Ashraf O, Bari V, Rafique MZ, Usman MU, Chisti I. Role of focused appendiceal computed tomography in clinically equivocal acute appendicitis. J Pak Med Assoc 2006;56:200-3.

23. Gamanagatti S, Vashisht S, Kapoor A, Chumber S, Bal S. Comparison of graded compression ultrasonography and unenhanced spiral computed tomography in the diagnosis of acute appendicitis. Singapore Med J 2007;48:80-7.

24. Wilson EB, Cole JC, Nipper ML, Cooney DR, Smith RW. Computed tomography and ultrasonography in the diagnosis of appendicitis: when are they indicated? Arch Surg 2001;136:670-5.

25. Rao PM, Boland GW. Imaging of acute right lower abdominal quadrant pain. Clin Radiol 1998;53:639-49.

26. Rao PM, Rhea JT, Novelline RA, Mostafavi AA, McCabe CJ. Effect of computed tomography of the appendix on treatment of patients and use of hospital resources. N Engl J Med 1998;338:141-6.

27. in't Hof KH, Krestin GP, Steijerberg EW, Bonjer HJ, Lange $\mathrm{JF}$, Becking WB, et al Interobserver variability in CT scan interpretation for suspected acute appendicitis. Emerg Med J 2009;26:92-4.

28. Old JL, Dusing RW, Yap W, Dirks J. Imaging for suspected appendicitis. Am Fam Physician 2005;71:71-8.

29. SCOAP Collaborative, Cuschieri J, Florence M, Flum DR, Jurkovich GJ, Lin P, et al. Negative appendectomy and imaging accuracy in the Washington State Surgical Care and Outcomes Assessment Program. Ann Surg 2008;248:557-63.

30. Inci E, Hocaoglu E, Aydin S, Palabiyik F, Cimilli T, Turhan AN, et al. Efficiency of unenhanced MRI in the diagnosis of acute appendicitis: comparison with Alvarado scoring system and histopathological results. Eur J Radiol 2011;80:2538.

31. Rezak A, Abbas HM, Ajemian MS, Dudrick SJ, Kwasnik EM. Decreased use of computed tomography with a modified clinical scoring system in diagnosis of pediatric acute appendicitis. Arch Surg 2011;146:64-7.

32. Escribá A, Gamell AM, Fernández Y, Quintillá JM, Cubells CL. Prospective validation of two systems of classification for the diagnosis of acute appendicitis. Pediatr Emerg Care 2011;27:165-9. 
33. Kostić A, Slavković A, Marjanović Z, Madić J, Krstić M, Zivanović D, et al. Evaluation of using Alvarado score and $\mathrm{C}$-reactive protein in diagnosing acute appendicitis in children. [Article in Serbian] Vojnosanit Pregl 2010;67:644-8. [Abstract]

34. Lintula H, Pesonen E, Kokki H, Vanamo K, Eskelinen M. A diagnostic score for children with suspected appendicitis. Langenbecks Arch Surg 2005;390:164-70.

35. Shrivastava UK, Gupta A, Sharma D. Evaluation of the Alvarado score in the diagnosis of acute appendicitis. Trop Gastroenterol 2004;25:184-6.

36. Kanumba ES, Mabula JB, Rambau P, Chalya PL. Modified Alvarado Scoring System as a diagnostic tool for acute appendicitis at Bugando Medical Centre, Mwanza, Tanzania. BMC Surg 2011;11:4.
37. Temple CL, Huchcroft SA, Temple WJ. The natural history of appendicitis in adults. A prospective study. Ann Surg $1995 ; 221: 278-81$.

38. Hansson LE, Laurell H, Gunnarsson U. Impact of time in the development of acute appendicitis. Dig Surg 2008;25:394-9.

39. Migraine S, Atri M, Bret PM, Lough JO, Hinchey JE. Spontaneously resolving acute appendicitis: clinical and sonographic documentation. Radiology 1997;205:55-8.

40. Cobben LP, de Van Otterloo AM, Puylaert JB. Spontaneously resolving appendicitis: frequency and natural history in 60 patients. Radiology 2000;215:349-52.

41. Andersson M, Andersson RE. The appendicitis inflammatory response score: a tool for the diagnosis of acute appendicitis that outperforms the Alvarado score. World J Surg 2008;32:1843-9. 